\title{
10. DETAILED X-RAY MINERALOGY OF CORE 9, SECTIONS 1 AND 2, HOLE 372 (BALEARIC RISE), DEEP SEA DRILLING PROJECT LEG 42A
}

\author{
Frédéric Mélières, Laboratoire de Géologie Dynamique, Université Pierre et Marie Curie, Paris, France
}

\section{INTRODUCTION}

Hole 372 of Deep Sea Drilling Leg 42A (Mediterranean Sea), is about $35 \mathrm{~km}$ east of the Menorca shelf (Balearic Basin) in 2734 meters of water. About 50 meters of upper Miocene evaporites were penetrated beneath 150 meters of Pliocene-Quaternary sediments. Below the evaporites, consisting of poorly recovered laminated gypsum and dolomitic marls (Cores 4 to 8 ), drilling penetrated into pre-Messinian to lower Burdigalian sediments. Core 9 (four sections recovered), immediately underlying the laminated gypsum, consists of nannofossil marls which are homogeneous in the lower part, but show a remarkable varve-like structure (alternation of gray and white submillimetric laminae) in the upper part. The boundary between these two zones lies in Section 2 at about $45 \mathrm{~cm}$ and coincides with a notable change in the faunal assemblage. Below this level the fauna indicates deposition in normal marine lower-middle bathyal conditions, whereas above, the depositional environment is shallow water and lagoonal (see Site 372 Report, Biostratigraphy). The laminae are present up to Section 1 at $97 \mathrm{~cm}$ where they are overlain by $20 \mathrm{~cm}$ of contorted sediments: possibly a result of drilling disturbance. This disturbed zone is topped by four small pieces of laminated gypsum which were artificially displaced by drilling (Figure 1).

The apparent change in depositional environment lead to passionate discussion among the shipboard scientists and the routine X-ray mineralogy data (Mélières et al., 1977), determined from only one sample per core section were not sufficient to add evidence to the debate. For this reason we undertook a detailed $\mathrm{X}$-ray mineralogical study on more closely spaced samples (every $10 \mathrm{~cm}$ ) in order to detect possible differences between the two facies. It was not our purpose, however, to evoke the problem of the age of these sediments (see Bizon, Cita, Müller, and Wright, Site 372 Report).

We analyzed 23 samples from Sections 1 and 2, without any pre-treatment, for bulk X-ray mineralogy following the method described in Mélières et al., (this volume). Because of the small size of the samples $(0.5$ cc), we did not make clay mineralogy determinations on the less than $2 \mu \mathrm{m}$ fraction.

\section{RESULTS AND DISCUSSION}

The analytical data are presented as mineralogical $\log s$ in Figure 1. The uppermost zone is probably disturbed (Section 1, 76-97 cm), and consequently the data from this interval are not taken into account in the discussion. (The presence of gypsum in the upper part of this zone indicates probable drilling contamination from the overlying laminated gypsum of Core 8.)

Our chief objective here is to see if the sudden change in depositional conditions, inferred from faunal assemblages, and occurring in Section 2 at $45 \mathrm{~cm}$, is reflected in the mineralogy of the sediments. For purposes of discussion we label "upper zone" the varved nannofossil marls (Section 1, 97-150 cm and Section 2, 0-45 cm), and "lower zone" the homogeneous sediments below Section 2, $45 \mathrm{~cm}$.

Generally, the mineralogy of the sediments throughout the two sections is relatively homogeneous. In fact, despite more or less pronounced fluctuations of the curves (Figure 1), there is neither a fundamental break in the percentages of the constituents nor appearance or disappearance of any mineral. The average percentages are very similar to those of the underlying sediments of Sections 3 and 4 of Core 9 (Mélières et al., this volume). Thus, on the whole, all of Core 9 belongs to the same mineralogical unit.

Nevertheless, slight but significant differences occur between the lower zone and the upper zone and several features allow us to distinguish them. The lower zone is characterized by a remarkable uniformity of the mineralogy consisting roughly of $60 \%$ terrigenous silicates (quartz, feldspar, and clay minerals) and $40 \%$ carbonates (mainly calcareous biogenic carbonate). This uniformity indicates a very constant rate of sedimentation. The stoichiometric dolomite, which is considered to be a detrital constituent, is present in very constant amounts, suggesting that this mineral is derived from the same sources as the silicate material. On the basis of the illite/chlorite ratio, these sources are thought to be far distant, probably in the Alpine area (Mélières et al., this volume). The striking stability of the stoichiometric dolomite/calcium-rich dolomite ratio (see Figure 1) confirms the monotonous character of the sedimentation.

In contrast, the upper zone is characterized by significant fluctuations in the percentages of all constituents. The remarkable correlation between quartz, feldspar, and clay mineral contents, as well as the stability of their relative proportions, indicates that the nature of the terrigenous constituents is the same as that in the lower zone. Presuming that deposition was in shallow water, these variations can be interpreted either as episodic incursions of water from the open sea 


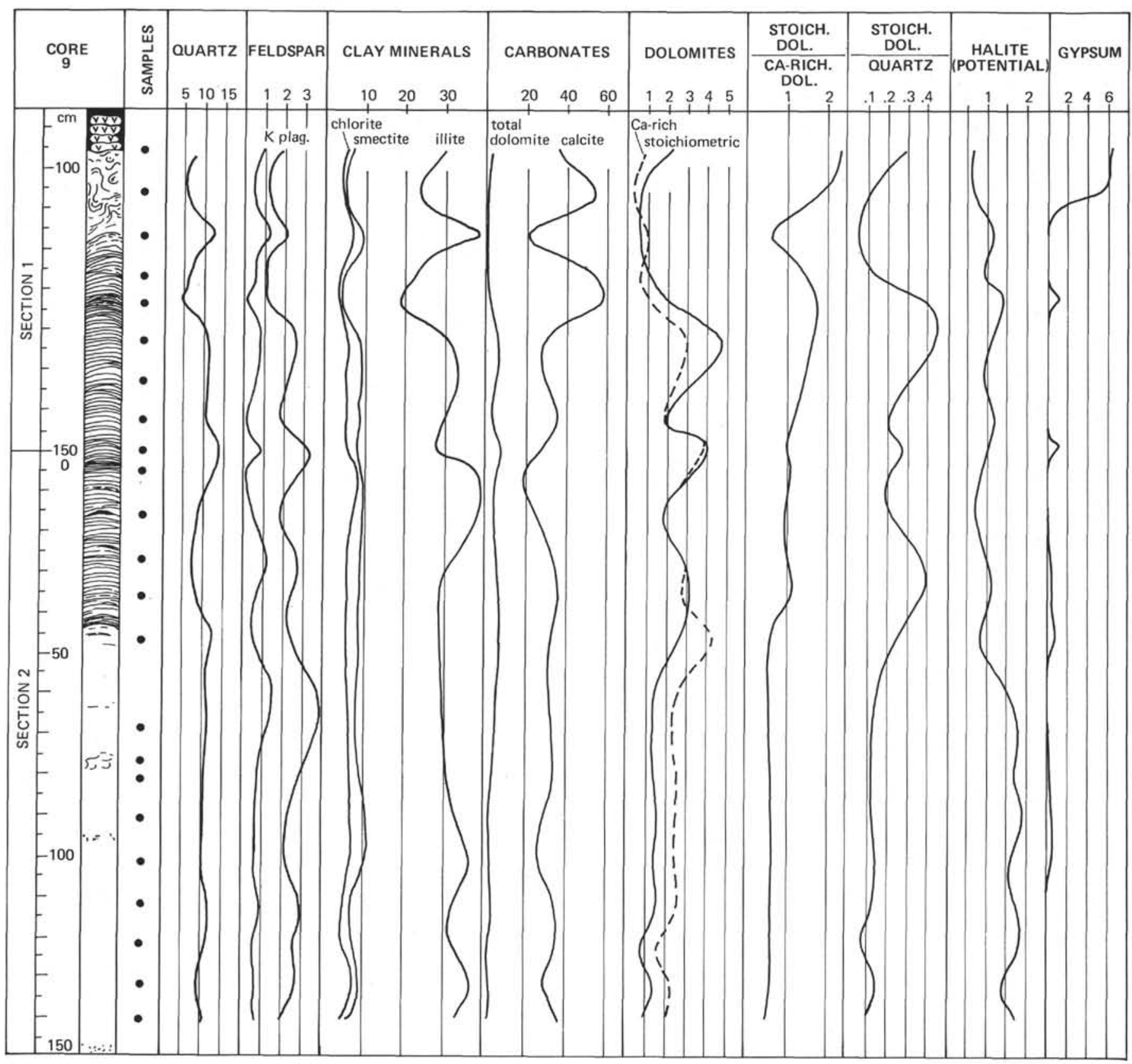

Figure 1. Mineralogical data, Hole 372, Core 9, Sections 1 and 2.

carrying terrigenous material similar to that deposited in the lower zone, or as the reworking (erosion and resedimentation) of proximal landmasses, the mineralogy of which was very similar to that of the underlying sediments (Serravallian and/or Tortonian).

A sharp break in the stoichiometric dolomite/calcium-rich dolomite ratio occurs at the boundary between the lower and upper zones. This break results from an increase in the stoichiometric dolomite content in the upper zone, which has much higher values than in the lower zone. This indicates that a second source of stoichiometric dolomite has been superimposed on the background of the general terrigenous input in the upper zone. This other source is probably the stoichiometric dolomite from the Jurassic sediments of Menorca (Bourrouilh, 1973). Discrepancies between sili- cates and stoichiometric dolomite curves (see Figure 1) confirm the individuality of the Menorca detrital input. This process is clearly demonstrated by the stoichiometric dolomite/quartz curve.

Thus, the sedimentation in the upper zone differs significantly from that in the lower zone and is characterized by fluctuations in the amount of detrital input from a regional source (Menorca). These facts are in good agreement with occurrence of a noticeably reduced water depth during deposition of the upper zone.

Of considerable interest, although of an incontestably speculative nature, are the data gained from the variations in the potential halite content of the sediments. This halite, appearing on the X-ray diffractograms and easily quantified with a good accuracy, does 
not exist in the sediment as a mineral. It results from the evaporation of the interstitial water when the sediments are dried in the laboratory: hence, "potential." In the lower zone, the potential halite content displays a rather constant value ranging between $1.5 \%$ and $1.9 \%$, with an average value of $1.61 \%$. In the upper zone, the potential halite content ranges between $0.7 \%$ and $1.4 \%$, with an average value of $0.95 \%$, (accuracy of these measurements is about 10\% relative.) The drop between these two mean values occurs at the boundary between the lower and upper zones, confirming their individuality. The salinity (in terms of $\mathrm{NaCl}$ ) of the interstitial water of a sediment analyzed by XRD, is related to the potential halite content by the equation:

$$
\mathrm{S} \%=10 \mathrm{H}(100-\mathrm{WC}) / \mathrm{WC}
$$

where $\mathrm{H}$ is the potential halite content of the dried sediment and WC is the water content of the sediment.

The salinity of the interstitial water as it appears today does not necessarily reflect the salinity of the water trapped in the new-born sediment. It obviously did not in the case at Site 372 where a continuous down-hole gradient of salinity occurs (McDuff and Gieskes, this volume). But precisely because of the continuity of this gradient and the proximity of the two compared zones, we suggest the following approach.

The water content is not documented with the same frequency as the potential halite content, and consequently we must take into account the two sources of water content data. On Glomar Challenger, the water content was measured by both syringe and cylinder methods (see Explanatory Notes, Chapter 1). Because these two methods produce slight discrepancies in the results, we consider both possibilities:

\section{(1) Syringe Method Data}

average water content in the lower zone: $23 \%$

average water content in the upper zone: $21 \%$

Using the above equation we obtain:

salinity $(\mathrm{NaCl})$ in the lower zone: $54 \%$ 。

salinity $(\mathrm{NaCl})$ in the upper zone: $35 \%$ 。

If we assume a depositional salinity in terms of $\mathrm{NaCl}$ of the interstitial water of $30 \%$ o (normal marine water, cf. Sverdrup, 1963 , p. 166) in the lower zone, then the mean value measured $(54 \% \circ)^{1}$ indicates a post-depositional contamination by brines bringing an excess of $24 \%$ in salinity $(\mathrm{NaCl})$. There is no fundamental reason why the upper zone would not have been influenced by such a contamination. (Despite the presence of laminae in the upper zone, the nannofossil marls offer a rather uniform plasticity and porosity to the whole section.) Thus, a correction of $-24 \%$ o in salinity would lead to a mean depositional salinity value (in terms of $\mathrm{NaCl}$ ) of $11 \%$ for the upper zone.

\footnotetext{
${ }^{1}$ The total salinity (all soluble constituents) is about $70 \%$ in the "normal marine" facies of Core 9 Section 2 (lower zone) as derived from the trend in the shipboard measurements in zones underlying Core 9. In terms of $\mathrm{NaCl}$, this yields a value of $59 \%$, which is in good agreement with the XRD value.
}

\section{(2) Cylinder Method Data}

An average value of $25 \%$ for the water content can be assumed for all of Core 9 as suggested by very constant values from the underlying sediments, above Core 24. Using the above equation, we obtain: salinity $(\mathrm{NaCl})$ in the lower zone: $48 \%$ 。 salinity $(\mathrm{NaCl})$ in the upper zone: $28 \%$ 。

With the same hypothesis as above (1), the correction for post-depositional contamination by brines $(-18 \%$ ) leads to a mean depositional salinity value (in terms of $\mathrm{NaCl}$ ) of $10 \%$ for the upper zone.

Thus, whichever way we choose, we obtain a very interesting result: the varved nannofossil marls of the upper zone were settled in a hyposaline environment, probably resulting from influxes of continental water. This result (1) confirms the shallow nature of the depositional medium, and (2) allows us to make a reasonable hypothesis about the origin of at least a part of the material comprising the upper zone. This material would result from the reworking (erosion and resedimentation) of proximal land-masses consisting of Serravallian and/or Tortonian sediments exposed to air during the Messinian regression.

Note: We do not discuss here the nature of the white laminae in the upper zone because the sampling interval was not sufficiently close to provide adequate control.

\section{CONCLUSIONS}

The detailed X-ray mineralogy study of Core 9, Sections 1 and 2 (Hole 372) leads to the following conclusions:

1) The varved nannofossil marls of the upper zone (above Section 2, $45 \mathrm{~cm}$ ), as well as the underlying homogeneous nannofossil marls (lower zone) are, on the whole, mineralogically very similar.

2) The deposition of the lower zone is remarkably uniform, as suggested by very constant values of the mineral constituents.

3) The deposition of the upper zone is characterized by variations in the intensity of regional detrital input (probably from the Alpine area), superimposed upon local detrital input (from Menorca). The whole interval was deposited in a hyposaline environment. These facts confirm that the water was shallow during deposition. Whether the regional detritus was derived from distant sources (seawater incursions), or from the reworking (erosion and resedimentation) of near-by landmasses consisting of earlier (Serravallian and/or Tortonian) sediments exposed during the Messinian regression, is a question to be addressed by biostratigraphers. As a result of the present work we would favor, at least in part, the second hypothesis.

\section{REFERENCES}

Bourrouilh, R., 1973. Stratigraphie, Sédimentologie et tectonique de l'ile de Minorque et du nord-est de Majorque (Baléares): Thèse, Université de Paris VI.

Sverdrup, H. V., Johnson, M. W. and Fleming, R. H., 1963. The Oceans: Englewood Cliffs, N.J. (Prentice-Hall, Inc.). 